\title{
Pendampingan Relawan Matematika Asyik (Rematika) Terhadap Siswa di Sekolah dan Anak-anak Nelayan Pinggir Pantai Kenjeran Surabaya
}

\author{
Achmad Hidayatullah \\ Universitas Muhammadiyah Surabaya \\ Email: achmad.pendmat@fkip.um-surabaya.ac.id
}

\begin{abstract}
ABSTRAK
Selama ini matematika menjadi matapelajaran yang sulit bagi siswa. Oleh karena itu sebagian orang tua memilih jalan mendatangkan guru privat untuk membantu anaknya memahami matematika. Pengabdian ini adalah pendampingan pembelajaran bagi siswa di SD Muhammadiyah 18 Surabaya dan anak-anak nelayan yang masih sekolah di daerah kenjeran surabaya. Pengabdian ini dilakukan oleh sejumlah realwan matematika asyik (REMATIKA) Universitas Muhammadiyah Surabaya. Para relawan membuat media inovasi pembelajaran sejumlah tujuh media untuk membantu siswa memhami matematika dengan cara asyik dan menyenangkan. Diantaranya Pembelajaran himpunan dengan media boneka pintar (BOPIN), smart turtle, KOTAMAT (kotak matematika), MERANGKA (menara perang matematika), Kurung Sakti, dan Pirates of Mathematics.
\end{abstract}

Kata Kunci: Media Inovas Pembelajaran, Relawan Matematika

\section{ABSTRACT}

So far, mathematics has become a difficult subject for students. Therefore some parents choose the way to bring in private teachers to help their children understand math. This devotion is the accompaniment of learning for students at SD Muhammadiyah 18 Surabaya and the fisherman children who are still in school kenjeran surabaya area. This devotion is done by a number of fun mathematical realists (REMATIKA) Muhammadiyah University of Surabaya. The volunteers make the media of learning innovation a number of seven media to help students memmami math with fun and fun way. Among them are learning of the set with the media of smart dolls (BOPIN), smart turtle, KOTAMAT (mathematical box), FRAMEWORK (mathematical war tower), Kurung Sakti, and Pirates of Mathematics

Keywords: Inovas Media Learning, Volunteer Mathematics

\section{PENDAHULUAN}

Matematika selalu hadir di setiap jenjang pendidikan dan kehidupan masyarakat. Ia menjadi alat untuk mempermudah hubungan transaksi dalam masyarakat. Sebagai bukti, selama ribuan tahun lalu masyarakat menggunakan matematika sebagai kebutuhan praktis dalam kehidupan, semisal untuk pengukuran tanah, pembuatan pyramida dan transaksi jual beli. Oleh karena itu ia tidak diajarkan akan tetapi menjadi praktek kehidupan sosial masyarakat. Saat ini kebutuhan matematika menjadi bagian penting 
dalam kehidupan sehingga ia menjadi disiplin ilmu tersendiri. Matematika ditransformasikan dalam pendidikan pada setiap jenjang. Meskipun sejak dini sudah mulai diajarkan, akan tetapi perlu diakui matematika masih sulit bagi sebagian orang. Seolah menjadi rahasia umum, sebagian mereka tidak memilih untuk sekolah karena takut pada pelajaran matematika. Jalan yang diambil oleh orang tua beragam, mulai dari memperpanjang jam belajar anak sampai menghindarkan anak. Petaka muncul ketika, guru privat yang dihadirkan juga tidak membuat siswa semakin mudah, akan tetapi menjadi lebih sulit bahkan tidak suka terhadap pelajaran matematika. Tentu fenomena tersebut, merupakan sebuah bencana bagi semua, jika banyak yang kesulitan mempelajari matematika.

Saat ini banyak sekolah yang belum memiliki fasilitas yang memadai untuk mendukung kegiatan belajar mengajar. Sekolah-sekolah di perkotaan pada umumnya telah memiliki berbagai fasilitas seperti LCD, laboratorium, ruangan ber Ac yang tentu membuat lingkungan belajar semakin nyaman. Akan tetapi fasilitas tidak hanya berhenti disitu, kebutuhan akan alat-alat pembelajaran seperti untuk pembelajaran matematika masih kurang. Mereka tidak punya alat-alat khusus yang berbasis inovasi guna mendukung pembelajaran matematika. Lebih-lebih sekolah yang berada di pinggiran, tentu memerlukan bantuan berbagai pihak guna melengkapi fasilitas pembelajaran. Untuk sekolah di pinggiran guru harus bekerja keras guna membuat alat-alat pendukung pembelajaran.

Selain itu, angka kemiskinan juga mempengaruhi tingkat pemahaman seseorang terhadap matematika. Mareka yang berada dalam perekenomian rendah tidak bisa mengenyam pendidikan dengan baik, sehingga tidak ada waktu untuk mempelajari matematika. Padahal praktek dalam kehidupan tidak bisa dilepaskan dari matematika. Banyak alat-alat dalam lingkungan sekitar yang bisa dimanfaatkan untuk membantu seseorang memahami pelajaran matematika. Anak-anak pada usia belajar yang berada di daerah pinggiran maupun pedalaman tingkat pendidikannya masih rendah, selain karena akses terhadap sekolah terkadang jauh, faktor ekonomi juga menjadi tantangan, tidak sedikit mereka yang pada usia produktif tersebut, diperbantukan oleh orang tuanya dalam rangka memnuhi kebutuhan hidup keluarga. Seperti anak-anak nelayan di pesisir pantai, pilihan membantu orang tua untuk mencari ikan dilaut merupakan urutan pertama. Hal tersebut menjadi tantangan bagi institusi pendidikan, agar apa yang dipelajari di sekolah sangat memiliki kaitan erat dengan lingkungan sekitar. Untuk anak-anak pesisir pantai akan lebih mudah jika mereka dibimbing mempelajari 
matematika yang tidak jauh dari kehidupan sebenarnya.

Setidaknya permasalahan diatas dapat diatasi dengan kreativitas bagi sebagian orang untuk menjadi relawan dalam mendampingi anakanak disekolah untuk belajar, dan mendampingi anak-anak di pesisir pantai yang kesulitan belajar matematika. Tentu pendampingan tersebut, harus berbeda dari proses belajar-mengajar seperti di sekolah yang terkadang masih menggunakan cara-cara konvensional. Cara yang dilakukan adalah dengan membuat media inovasi pembelajaran matematika yang kreatif guna, mempermudah dan membuat siswa lebih nyaman bermain dan belajar matematika. Media memegang peranan penting dalam pembelajaran, semakin baik media yang digunakan maka siswa akan semakin tertarik dalam belajar matematika. Selama ini siswa tidak senang terhadap pelajaran ini, misal karena faktor metode yang digunakan dan tidak didukung dengan media pembelajaran yang memadai.

\section{Untuk} menunjang kemampuan siswa dalam belajar matematika tersebut, siswa di ajarkan menggunakan berbagai macam sumber dan media pembelajaran yang dapat menambah kemampuan siswa dalam berinteraktif, berfikir logis, kreatif dan sistematis. Hudojo (2005: 160) mengatakan bahwa untuk memudahkan mengajarkan suatu pengertian/konsep salah satunya menggunakan obyek-obyek, gambar dan benda-benda konkret atau semi konkret, dalam hal ini diperlukan suatu media/alat peraga yang bisa membantu membawa materi dari konkret menuju ke abstrak. Media pembelajaran merupakan salah satu aspek penting dalam proses pendidikan, menurut Schramm (1982) media pembelajaran adalah teknologi pembawa pesan yang dapat dimanfaatkan untuk keperluan pembelajaran. Gagne (1970) menyatakan bahwa media adalah berbagai jenis komponen dalam lingkungan siswa yang dapat merangsangnya untuk belajar.

Sedangkan menurut Mahnun (2012) media adalah berkaitan dengan perantara yang berfungsi menyalurkan pesan dan informasi dari sumber yang akan diterima oleh si penerima pesan yang terjadi dalam proses pembelajaran. Manfaat media pembelajaran dalam proses belajar siswa, yaitu pembelajaran akan lebih menarik perhatian siswa sehingga dapat menumbuhkan motivasi belajar; bahan pembelajaran akan lebih jelas maknanya sehingga dapat lebih dipahami oleh siswa dan memungkinkannya menguasai dan mencapai tujuan pembelajaran; metode mengajar akan lebih bervariasi, tidak se mata-mata komunikasi verbal melalui penuturan kata-kata oleh guru, sehingga siswa tidak bosan dan guru tidak kehabisan tenaga, apalagi kalau guru mengajar pada setiap jam pelajaran; (rifai dan sudjana, 2009). Miarso (2004) mengemukakan bahwa media merupakan segala sesuatu yang dapat 
digunakan untuk menyalurkan pesan yang dapat merangsang pikiran, perasaan, perhatian, dan kemauan siswa sehingga terjadi proses belajar.

Oleh karena itu, untuk mengatasi berbagai persoalan diatas, maka pengabdian ini dilakukan dengan cara membentuk Relawan Matematika Asyik (Rematika) untuk melakukan pendampingan terhadap sekolah-sekolah dan anak-anak usia sekolah di pesisir pantai kenjeran. Peran relawan matematika ini merupakan bagian penting dari matarantai permasalahan dalam matematika. Relawan sebenarnya cikal bakal dari disiplin pekerjaan sosial, bekerja tanpa pamrih, inisiatif sendiri, membantu masyarakat yang kesulitan. Menurut L. Tobing dkk (2008) relawan adalah seseorang atau sekelompok orang yang secara ikhlas karena panggilan nuraninya memberikan apa yang dimilikinya (pikiran, tenaga, waktu, harta dan lainnya) kepada masyarakat sebagai wujud tanggung jawab sosialnya tanpa pamrih baik berupa imbalan, kekuasaan, kedudukan atau kepentingan maupun karier. Meminjam istilah yang digunakan oleh Mitchell Rematika merupakan jenis dari direct service volunteers, yaitu relawan pelayanan langsung yang mungkin terlibat dalam aktivitas-aktivitas seperti konseling, rekreasi, dan pengajaran. Kecenderungannya sekarang adalah mengkaitkan klien, terutama yang melatih relawan sebagai bagian dari rencana intervensi keseluruhan.
Seringkali relawan terlatih menangani saluran telepon krisis, atau hotline, dan merujuk penelepon ke sumber-sumber komunitas yang sesuai.

\section{METODE PELAKSANAAN}

Pelaksanaan pengabdian ini dilakukan di sekolah dasar Muhammadiyah 18 surabaya dan lingkungan masyarakat kenjeran pinggir pantai dengan pusat kegiatan SD Muhammadiyah bahari surabaya. Pelaksanaannya dilakukan serangkaian, pendampingan pembelajaran dilaksanakan 2 hari. Untuk hari kedua di daerah kenjeran dilakukan di tengah-tengah perkampungan nelayan kenjeran surabaya.

Sasaran pengabdian ini terbagi menjadi dua bagian yang saling terkait. Pertama, yaitu siswa sekolah dasar Muhammadiyah 18 Surabaya kelas 5. Pada kelas ini siswa masih kesulitan dalam belajaran matematika khususnya bangun datar dan keaktivannya kurang. Sedangkan sasaran kedua adalah anak-anak nelayan diperkampungan kenjeran surabaya. Mereka kurang memiliki semangat untuk belajar matematika karena selama ini merasa bosan dan pembelajaran kurang menarik minat. Oleh karena itu, maka dalam pengabdian menggunakan alat inovasi ini harapannya agar mereka memiliki motivasi belajar matematika yang baik dan tertarik untuk belajar matematika. 
Kegiatan yang dilakukan berupa pendampingan terhadap siswa disekolah dan anak-anak pesisir pantai kenjeran. Pendampingan dalam pembelajaran matematika yang lebih asyik dan menyenangkan. Adapun mengenai materi, disesuaikan dengan standard media inovasi yang dibuat, yaitu mengenai operasi bilangan, pengenalan bangun datar, bangun ruang serta himpunan. Pada proses pengabdian ini, permasalahan pendidikan menjadi sasara utama. Yaitu bagaimana mengaktifkan dan merubah manajemen pembelajaran yang telah ada dengan menggunakan pendukung media inovasi pembelajaran. Selain itu, selain pendampingan berupa proses pembelajaran dengan media inovasi berbasis alat laut di tengahtengah perkampungan masyarakat oleh relawan matematika Asyik (Rematika). Kegiatan yang digunakan dalam pengabdian ini berupa pendampingan, pengawalan, ceramah dan diskusi. Tentunya dengan model ceramah dalam konteks pengetahuan teori, sedangkan pengawalan dan pendampingan dilakukan dalam bentuk aksi nyata pengabdian dengan media inoavasi. Selain itu diberikan berbagai model permainan inovasi pembelajaran. Adapun mengenai materi yang digunakan adalah: (1) pembelajaran himpunan dengan media boneka pintar (BOPIN), (2) pembelajaran bangun datar dengan media smart turtle, (3) himpunan dengan media pembelajaran KOTABIL (Kotak Bilangan), (4) bangun datar dengan media MERANGKA (Menara Perang Matematika), (5) media bangun datar dan operasi bilangan dengan Kurung Sakti, (6) pirates of mathematics I untuk mempelajari operasi bilangan, dan (7) pirates of mathematics II untuk mempelajari operasi bilangan.

\section{HASIL DAN PEMBAHASAN.}

Hasil dalam pengabdian ini berupa capaian proses dalam kegiatan pendampingan yang fokus pada aspek pembelajaran matematika dengan media inovasi pembelajaran. Memang untuk menarik antusiasme dan meningkatkan minat siswa dalam belajar matematika tidak hanya dengan mengajar menarik, akan tetapi mereka juga membutuhkan media inovasi dalam pembelajaran sehingga mereka benar-benar terlibat dalam pembelajaran. Mereka benar-benar belajar bermakna. Pada pengabdian ini melibatkan guru, para relawan matematika asyik (Rematika) serta dua orang dosen pendamping. Sedangkan anggota dari relawan matematika asyik sendiri diambil dari pendaftar yang menyetorkan alat inovasi masing-masing. Sehingga total dalam pengabdian ini ada 6 media dan 18 orang relawan matematika. Adapun pelaksanaannya dilakukan selama dua hari, hari pertama dilakukan di sekolah dasar Muhammadiyah 18 Surabaya dalam bentuk pembelajaran terhadap siswa. Untuk setiap media ternyata bisa digunakan terhadap maksimal 5 orang siswa. Sehingga para relawan 
yang masing- masing tim berjumlah 3 orang bisa mendampingi 3 orang siswa. Sehingga setiap meja dan setiap media memiliki tema berbeda. Fokus dalam pengabdian ini dalam aspek pembelajaran matematika agar anak-anak mudah memahami dan asyik dalam belajar matematika.

\section{Pembelajaran himpunan dengan media Boneka Pintar (Bopin)}

Himpunan merupakan suatu kumpulan objek atau benda yang dapat didefinisikan dengan jelas. Artinya keanggotaannya jelas, dapat dengan tegas disebutkan. Cara menjelaskan himpunan bisa menggunakan kata-kata, menuliskan anggotanya dan dengan cara menggunakan notasi pembentuk

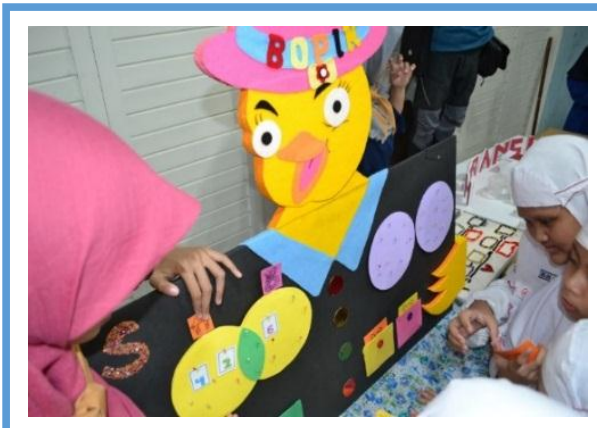

Relawan Matematika Asyik mengajarkan himpunan untuk anakk SD dengan BOPIN

\section{Pembelajaran bangun datar dengan media Smart Turtle}

Bangun datar merupakan bangun dua dimensi yang hanya memiliki panjang dan lebar, yang dibatasi oleh garis lurus atau lengkung.(Pramita, 2015). Banyak contoh dari bangun datar seperti persegi, persegi panjang, segitiga, himpunan. Sedangkan notasi himpunan menggunakan huruf kapital, sedangkan anggotanya ditulis menggunakan kurung kurawal (Wahyono dan Fahamsyah, 2008 ). (Memang harus diakui selama ini siswa masih sulit untuk memahami tentang himpunan. Umumnya selama ini media yang digunakan oleh guru dalam mempelajari himpunan adalah dengan menggunakan buku yang telah ada, sehingga guru cukup menjelaskan gambar yang berkaitan dengan materi himpunan. Tentu hal tersebut mebuat siswa merasa bosan, karena tidak ada yang menarik dalam kegiatan tersebut. Dengan menggunakan media Bopin ini nampak siswa memiliki semangat dan antusiasme dalam mempelajari himpunan.

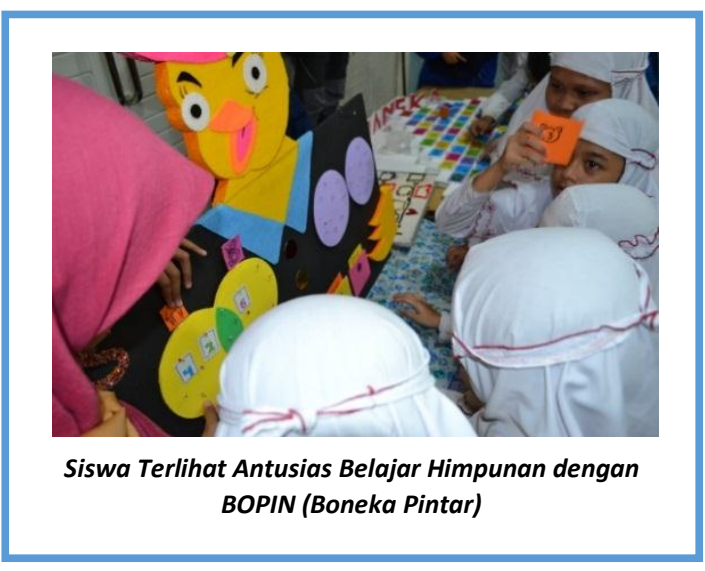

lingkaran dll. Untuk anak pada tingkat sekolah dasar umumnya diajarkan tentang sifat-sifat bangun datar dan bermuara menghitung luas dan keliling dari bangun datar tersebut. Selama ini siswa belajar bangun datar dengan menggunakan peraga tetapi tetapi jarang yang berupa Game atau permainan. Smart 
Turtel ini medai pembelajaran bangun datar bernuanasa permainan. Sehingga siswa tidak merasa bosan. Pada kali ini Relawan Matematika Asyik (Rematika) menggunakan media smart turtle ini mengajarkan tentang bangun datar. Permainan ini sejenis ular tangga, namun bentuk dari smart turtle sendiri berwujud kura-kura, berwarna hijau. Dengan media ini ini siswa menjadi lebih semangat belajar bangun datar. Pada permainan ini, siswa yang bermain melemparkan dadu, yang terdiri dari angkat dan ada sejumlah pertanyaan pada dadu tersebut seperti ciri-ciri, rumus dll. Ketika dadu dilempar maka pemain akan menjalankan batunya sasuai angka dadu, nah disitu tepat dengan bangun datar, dan disesuaikan dengan pertanyaan pada dadu. Jika siswa mampu menjawab maka ia boleh melanjutkan langkah.
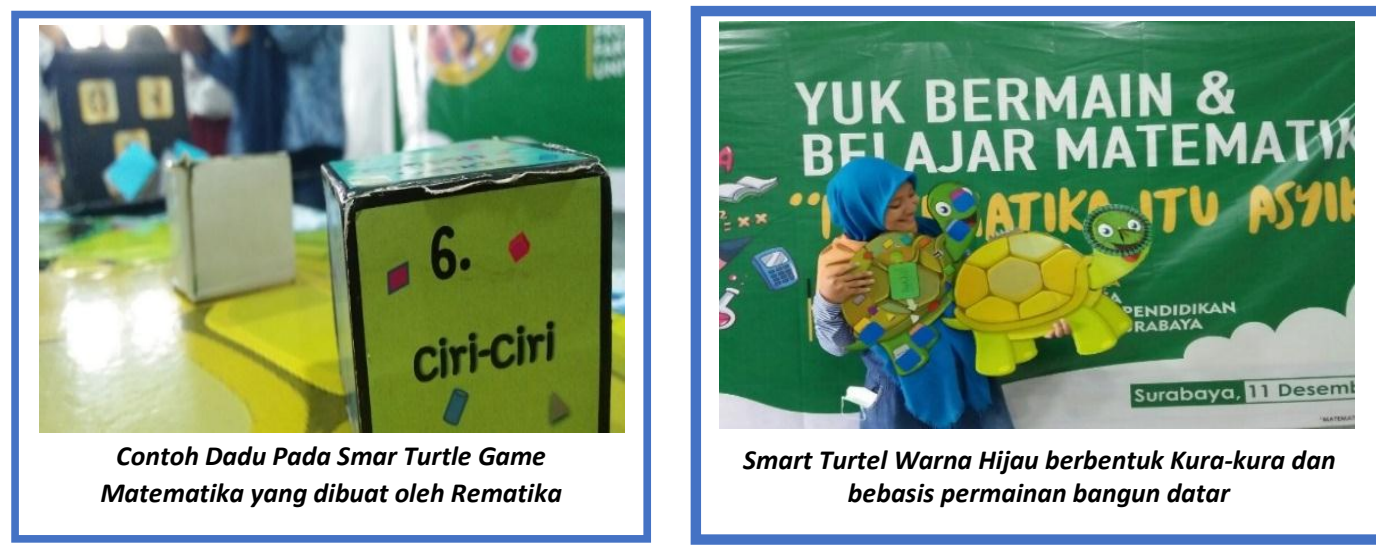

Smart Turtel Warna Hijau berbentuk Kura-kura dan bebasis permainan bangun datar

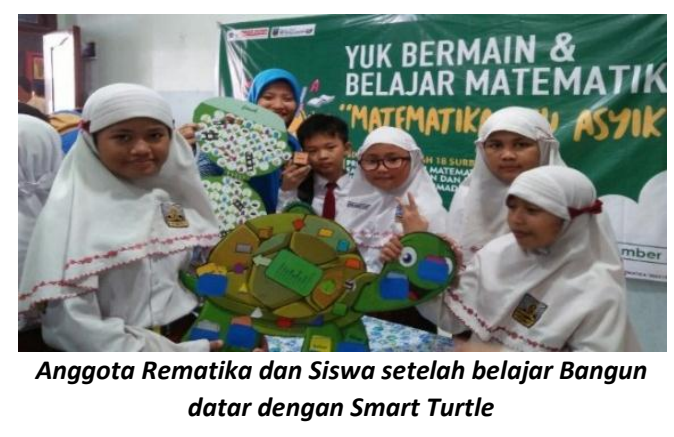

3. Mencari FPB dan KPK dengan media pembelajaran Kotamat (Kotak Matematika)

Faktor persekutuan terbesar (FPB) adalah pembagi terbesar dari dua bilangan atau lebih. FPB biasanya digunakan sebagai salah satu cara menyederhanakan hitungan. Dalam kehidupan sehari-hari FPB bisa digunakan untuk sakala denah bangungan, skala peta, membuat perbandingan jumlah penduduk. Sedangkan Kelipatan Persekutuan Terkecil (KPK) adalah penjumlahan berulang dari bilangan yang sama. KPK biasanya digunakan pada oprasi penjumlahan atau pengurangan suatu pecahan, dimana penyebut suatu 
pecahan perlu disamakan terlebih dahulu. (Wiratno, dkk, 2011). Namun selama ini untuk pembelajaran FPB dan KPK ini siswa masih mengalami kesulitan. Oleh karena itu dalam pengabdian ini Rematika tidak lupa membuat media pembelajaran yang membahas kedua materi tersebut. Dengan media Kotamat ini siswa menjadi lebih aktif dan belajar matematika lebih menyenangkan. Pada pembelajaran ini Relawan menuliskan angaka dari FPB dan KPK yang akan dicari. Kemudian ditentukan faktorisasi prima dari angka-angka tersebut dengan menuliskan pada papan bantu yang tersedia disamping kotak bunga . Kemudian dimasukkan biji bunga sesuai dengan faktorisasi prima yang telah ditentukan kedalam kotak matematika berdasarkan angka dan warna yang sesuai. Adapun Syarat untuk menentukan FPB.

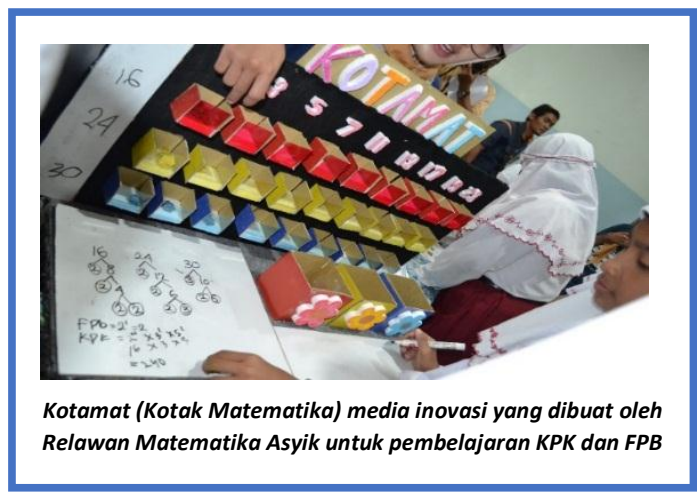

\section{Matematika dengan media Merangka (Menara Perang Matematika)}

Permainan matematika yang ada selama ini diantaranya ada monopoli, ular tangga, dakon dll. a. Setiap kolom kotak harus terisi dengan biji bunga

b. Pilihlah kotak dengan biji bunga yang paling sedikit disetiap kolom kotak

c. Kalikanlah angka yang sesuai dengan kotak yang telah terpilih dan biji bunga didalamnya sebagai pangkat angka terseut

d. Hasil perkalian tersebut merupakan hasil FPB

Sedangkan syarat untuk menentukan KPK.

a. Setiap kolom kotak tidak harus terisi biji bunga, minimal 1 kotak yang terisi dalam setiap kolom

b. Pilihlah kotak dengan biji bunga yang paling banyak disetiap kolom kotak

c. Kalikanlah angka yang sesuai dengan kotak yang telah terpilih dan biji bunga didalamnya sebagai pangkat angka tersebut

d. Hasil perkalian tersebut merupakan hasil KPK

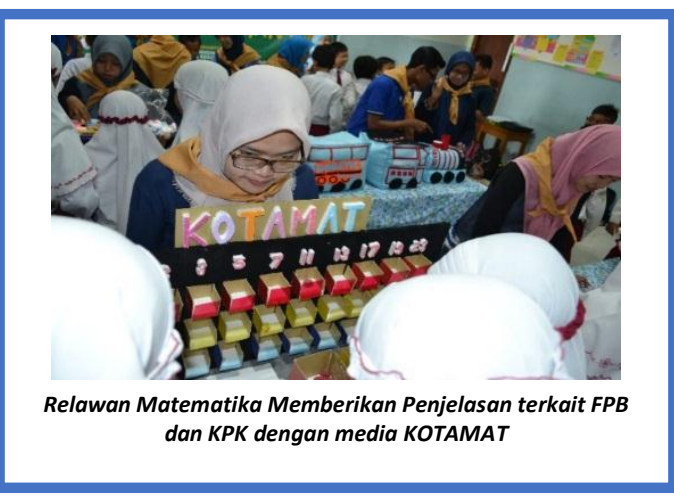

Tentu media tersebut sudah banyak di masyarakat, oleh karena itu Merangka ini media sejenis ular tangga akan tetapi dimodifikasi guna menarik minat anak bermain dan belajar matematika. Dengan belajar dan 
bermain matematika harapannya anak-anak pinggir pantai kenjeran dapat lebih aktif dan memiliki motivasi kuat untuk belajar. Merangka ini dibuat dari bahan-bahan bekas, agar anak-anak nelayan mudah membuatnya. Permainan ini sangat cocok untuk anak-anak, khususnya mereka yang berada dalam ekonomi lemah karena bahan-bahan dari media ini, berasal dari barang bekas. Yaitu, steroform, triplek bekas, tutup botol dan kertas.

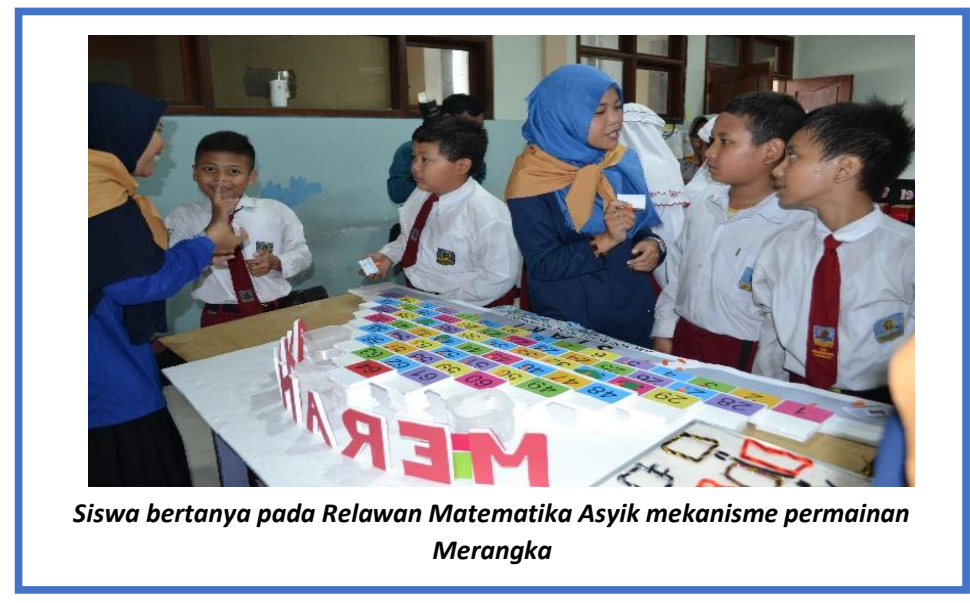

\section{Media bangun datar dan operasi bilangan dengan Kurung Sakti}

Secara umum operasi bilangan terdiri dari empat macam yaitu penjumlahan, pengurangan, perkailian dan pembagian. Selama ini siswa umumnya merasa kesulitan ketika melakukan perkalian dan pembagian. Media yang selama ini ada adalah sempoa. Selain sempoa media tradisional yang ada selama ini adalah permainan dakon. Namun belum ada media operasi bilangan yang bisa digunakan sekaligus mempelajari bangun datar dan bangun ruang. Oleh karena itu Relawan matematika membuat alat inovasi Kurung Sakti untuk memberikan pemahaman yang mudah bagi siswa mengenai operasi bilangan dan bangun ruang serta bangun datar. Media tersebut adalah kurung. Media ini sangat cocok untuk anak-anak pinggiran dan anak-anak nelayan yang bisa memanfaatkan kurung bekas guna mempelajari operasi bilangan tersebut. Karena media ini sangat mudah didapatkan dan secara ekonomi bisa dijangkau. Pada pembelajaran ini Relawan memberikan permainan menggunakan kurung sakti. Sehingga siswa nampak antusias mempelajari operasi bilangan sekaligus bangun datar dan bangun ruang. Karena bagi mereka selama ini, kurung yang ada hanya untuk tempat atau rumah hewan piaraan. Akan tetapi saat ini bisa dijadikan alat untuk permainan sekaligus belajar matematika dengan asyik. 


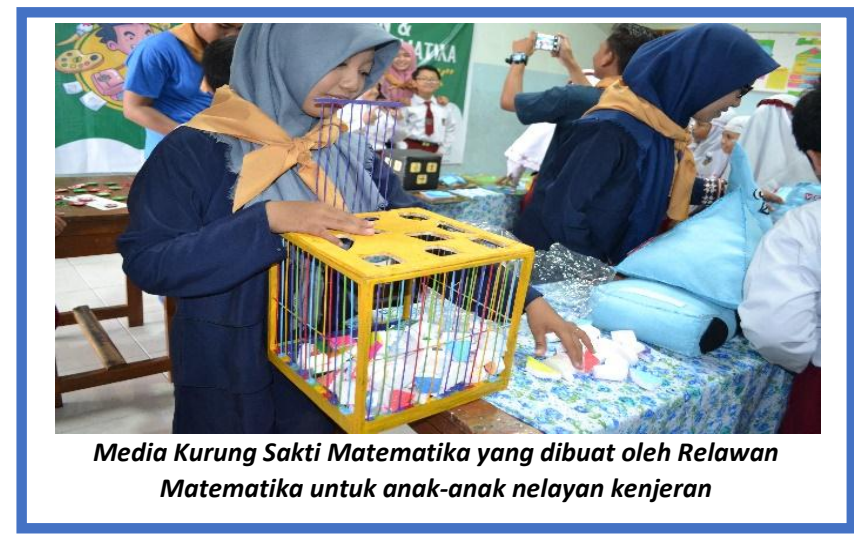

\section{Pirates of Mathematics I dan II untuk mempelajari operasi bilangan}

Seperti halnya kurung sakti, pirates of Mathematics ini dibuat oleh relawan matematika agar siswa lebih mudah mempelajari matematika dengan cara asyik dan meyenangkan. Namun media ini dikhususkan bagi anak-anak nelayan pinggir pantai dikenjeran surabaya. Sedangkan bahan dari alat-alat ini diambil dari bahan laut seperti kerang dan pasir. Selama ini kerang dan pasir biasanya digunakan untuk hiasan saja kadang dibuang tanpa ada guna. Oleh karena itu Relawan matematika melihat hal

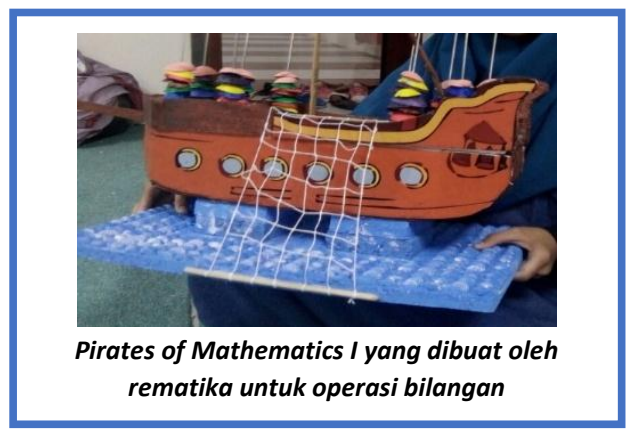

\section{SIMPULAN}

Kesulitan dalam memahami matematika memang telah menjadi rahasia umum. Kesulitan dalam mempelajari matematika merupakan tersebut memiliki potensi yang bagus untuk anak-anak khusunya mereka yang berasal dari keluarga nelayan. Dengan menggunakan alat-alat tersebut, media pembelajaran ini memiliki nuansa etnomathematics yang memiliki ciri khas lingkungan. Bentuknya disesuaika berbentuk perahu, agar anak-anak tidak lupa terhadap lingkungannya. Media ini digunakan untuk mempeljari operasi bilangan dan aljabar khususnya sistem persamaan linier. Inspirasi dari media tersebut lahir dari film Pirates of Carribean, sehingga menjadi pirates of mathematics.

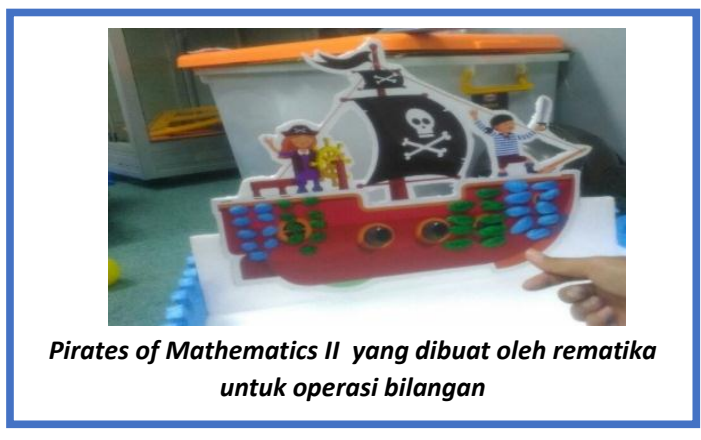

bagian dari bencana dalam pembelajaran. Oleh karena itu, relawan matematika dalam pengabdian ini mencoba memecahkan persoalan yang telah 
lama, dengan membuat media inovasi pembelajaran matematika dengan bermacam-macam bentuk. Pada pengabdian yang dilakukan di sekolah SD Muhammadiyah 18 Surabayan dan pada siswa yang berasalah dari anak-anak nelayan kenjeran surabaya ini memang menarik minat dan antusias. Pendampingan pembelajaran ini juga memberikan informasi bahwa anakanak akan tertarik, dan asyik belajar matematika jika menggunakan media yang inovatif dalam pembelajaran. Banyak alat-alat dari lingkungan sekitar yang bisa dimanfaatkan untuk media pembelajaran, akan tetapi selama ini guru jarang memanfaatkannya. Kehadiran Relawan Matematika Asyik ini memberikan manfaat bagi kekurangan yang selama ini ada dalam pembelajaran untuk daerah surabaya.

\section{DAFTAR PUSTAKA}

Gagne, R. (1970). Principles of instructional design. New York: Halt, Rinehart and Winston

Hudojo, Herman. (2005). Pengembangan kurikulum dan pembelajaran matematika. Malang: Universitas Negeri Malang

Miarso, Yusufhadi. (2011). Menyemai Benih Teknologi Pendidikan, Jakarta: Prenada Media Group

Pramita, Lynda dan Forum Guru Menulis Indonesia. (2015). Buku master SD/MI 5 in I. Jakarta: Media Pusindo
Rifai, Ahmad dan Sudjana, Nana. (2009). Media Pengajaran. Bandung: Sinar Baru Algesindo

Sudjana, Nana. (1990). Media Pendidikan, Bandung: Sinar Baru

Uria Regina Irene L. Tobing, Fentini, Nugroho, Tehuteru, Edi Setiawan. (2008). Peran relawan dalam memberikan pendampingan kepada anak penderita kanker dan keluarganya. Indonesian Journal of Cancer 1, 35 -39

Wahyono, Endro dan Fahamsyah, Andy. (2008). Super refrensi rumus matematika SD, SMP, dan SMA. Jakarta: Wahyu Media.

Wiratno, Siswo dkk. (2011). Bunda jagoan matematika. Jakarta: Grasindo 